\title{
原発性肝癌に対する肝動脈塞栓術併用肝切除の検討
}

\author{
国立長崎中央病院外科，“同 病理 \\ 古川 正人 中田 俊則 山田 隆平酒井敦 \\ 伊藤新一郎 瀬戸口正幸 前田 滋 千葉 憲哉 \\ 八十川要平 永田 寿礼 藤井 秀治*

\section{COMBINATION THERAPY BY TRANSCATHETER ARTERIAL EMBOLIZATION AND HEPATIC RESECTION FOR HEPATOCELLULAR CARCINOMA} \\ Masato FURUKAWA, Toshinori NAKATA, Ryuhei YAMADA, \\ Tsutomu SAKAI, Shinichiro ITO, Masayuki SETOGUCHI, \\ Shigeru MAEDA, Kenya CHIBA, Yohei YASOGAWA, \\ Toshinori NAGATA and Hideharu HUJII* \\ Department of Surgery and Department of Pathology*, \\ National Nagasaki-Chuo Hospital
}

\begin{abstract}
原発性肝細胞癌10例に対して, TAE 併用肝切除を行った. 手術死亡 2 例を除く 8 例中 5 例が 2 年を 経過して生存中であるが， 3 例が再発死亡した，TAEの有効性をみるために, TAE 後早期に他病死 した 2 例の剖検例を加えた12例の肝を組織学的に検索した. TAEにて主腫堭の中心部には強い壊死 がみられたが, 被膜外漫潤, 門脈内腫瘍栓, 娘結節には効さ難かった。しかし, 塞栓物質を細くして より末梢まで塞栓したり, 徐放性の抗癌剤を用いた chemo-embolization を行ったり, さらに, TAE の回数を増した例には有効例がみられた。したがって, TAE 併用肝切除による肝癌の治療成績の向上 には, TAEの方法や塞栓物質の改良が必要であると考学られた。
\end{abstract}

事引用語：原発性肝細胞癌, 肝硬変併存肝癌, 肝動脈塞栓術, 肝動脈塞栓術併用肝切除

\section{I.はじめに}

最近の肝臓外科の進歩は目ざをしく, 肝切除そのも のは, 術式や術前術後管理も確立され安全に行われる よらになってきたが，本邦に拉ける原発性肝癌では， その大部分に肝硬变が併存している゙ために，定型的 な肝葉切除では, 術後の肝不全による死亡も少なくな く，また，遠隔成績も満足すべき状態ではない，

一方, 切除不能肝癌に対して行われている肝動脈塞 栓術 (transcatheter arterial embolization 以下 TAE と略す)が，著明な延命効果を挙げていること少はよく 知られて拉り，われわれは，肝切除にさきだってこの TAEを行穴ば, 肝癌細胞の viability が低下し, あるい

$<1986$ 年 3 月 12 日受理 >別刷請求先 : 古川 正人 干856 大村市久原郷1001 国立長崎中央病院外科
は, 壊死に陥り, 術中の癌細胞の散布が防止され, 上 り根治的な肝切除が行学るのではないかと考光, 原発 性肝癌治療成績の向上をめざして, 昭和56年より $\mathrm{TAE}$ 併用肝切除を施行してきた。

今回は，われわれの施設に打ける，これまでの原発 性肝癌切除例の手術成績を報告するとともに, 少数例 ではあるが TAE 後に切除した肝癌の病理組織学的検 討より，肝癌に対する TAEの有用性について考察を 加えて報告する。

\section{II. 対 象}

昭和 46 年 1 月より昭和 60 年 6 月までに，われわれの 施設で切除した原発性肝癌は31例で, このらち肝細胞 癌は28例, 胆管細胞癌が 3 例で, 男性 21 例, 女性 10 例 と男性に多かった。肝硬変併存例は 31 例中 21 例 $67.7 \%$ で, 胆管細胞癌に併存例はなく, いずれも肝細胞癌に 
併存していた（表 1 ）.

なお，TAEの有効性の検討のためには，TAE 併用 肝切除例10例之, TAE 後短期間で他病死した 2 例(脳 内出血 1 例, 脳梗塞 1 例)の剖検例の肝組織を用いた。

$$
\text { III. 成 }
$$

1. 肝硬変の併存之手術死亡

肝細胞癌 28 例中肝硬変の併存は 21 例 $75 \%$ で，手術死 亡の 6 例（肝不全 5 例, 食道静脈瘤破裂 1 例）はすべ て肝硬変併存例であり, 肝硬変併存肝癌の手術死亡率 は21例中 6 例 $28.6 \%$ であった。

胆管細胞癌には, 肝硬変の併存はなく, 手術死亡も みられなかった（表 1)。

2. 手術術式と手術成績

胆管細胞癌 3 例を除く原発性肝細胞癌28例の手術術 式をみると, 肝二区域切除 9 例，一区域切除 8 例，亜 区域ないし部分切除11例である.

これを肝硬変併存の有無で分けてみると，肝硬変併 存例では, 肝二区域切除では 6 例中 2 例, 一区域切除 では 7 例中 4 例に手術死亡が認められたが，亜区域な いしは部分切除を行った 8 例には手術死亡が認められ なかった，一方，肝硬変非併存例では，一〜二区域切 除 4 例，亜区域ないしは部分切除を 3 例に行ったが, 手術死亡は 1 例涼めなかった（表 2).

3. 術前 TAE と手術成績

原発性肝細胞癌切除例28例中, 術前 TAEを行った のは10例であるが，手術死亡は，TAE (一) 群で18例

表 1 原発性肝癌切除症例

国立長崎中央病院外科

\begin{tabular}{|c|c|c|c|}
\hline & 男 & 女 & st \\
\hline 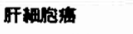 & 19 (3) 列 & 9 (3) 例 & 28 (6) 例 \\
\hline 旰喽变 $(+)$ & $12(3)$ & $9(3)$ & $21(6)$ \\
\hline 厈政表(一) & $7(0)$ & 0 & $7(0)$ \\
\hline 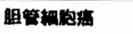 & $2(0)$ & $1(0)$ & $3(0)$ \\
\hline 旰理卒 $(+)$ & 0 & 0 & 0 \\
\hline 估霆变 $(-)$ & $2(0)$ & $1(0)$ & $3(0)$ \\
\hline 幛 & $21(3)$ & $10(3)$ & $31(6)$ \\
\hline
\end{tabular}

表 2 原発性肝癌切除術式（除：胆管細胞癌）

\begin{tabular}{|c|c|c|c|}
\hline & 杆政 $(+)$ & 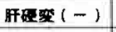 & tit \\
\hline f & $6(2)$ & $3(0)$ & $9(2)$ \\
\hline 一区域好睬 & $7(4)$ & $1(0)$ & $8(4)$ \\
\hline 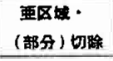 & $8(0)$ & $3(0)$ & $11(0)$ \\
\hline it & $21(6)$ & $7(0)$ & $28(6)$ \\
\hline
\end{tabular}

中 4 例, TAE $(+)$ 群で10例中 2 例と差は認めなかっ た。肝硬変併存例は 15 例と 6 例で手術死亡はそれぞれ $22.2 \% ， 20.0 \%$ あった。

さらに, 手術術式でみると, 術前 TAE (-)群では, 肝一区域切除 6 例，二区域切除 6 例，垔区域ないしは 部分切除 6 例であり，術前 TAE（+）群ではそれぞれ 3 例， 2 例， 5 例であるが，手術死亡はいずれも肝硬 変併存例の肝一 二 二域切除例に認められた（表 3 ）.

4. 術後生存期間

術後の生存期間を TAE の有無でみると, 術前 TAE 非施行例では，采んん゙の症例が 6 力月以内に再発死 亡したが， 4 年以上生存した例が 4 例みられ，そのう ちの 2 例は， 6 年 4 力月後, 7 年後に肝不全にて死亡 し, 残る 2 例が生存中である. 一方, 術前 TAE 施行例 では,やや術後の生存期間が延長したよらにみ党たが, いまだ長期生存例を得る段階ではなく, 生存例が 5 例 みられるものの, いずれも 2 年末満の症例であり， 3 例は再発にて 8 カ月，18カ月，24カ月で死亡した（図 1 ).

5. TAE 併用肝切除症例

対象症例は TAE 併用肝切除症例10例と TAE 後短 期間で死亡した 2 例の剖検例 (症例11，12）である（表

表 3 原発性肝細胞癌妡除術式

\begin{tabular}{|c|c|c|c|c|c|}
\hline & \multicolumn{2}{|c|}{ 活萑TAE $(-)$} & \multicolumn{2}{|c|}{ 速前TAE (+) } & \multirow{2}{*}{ at } \\
\hline & F姃变 $(+)$ & 的理要 $(-)$ & 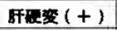 & ffre $(-1)$ & \\
\hline \multirow{3}{*}{ 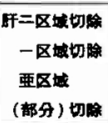 } & $4(1)$ & $2(0)$ & $2(1)$ & $1(0)$ & \multirow{3}{*}{$\begin{array}{r}9(2) \\
8(4) \\
11(0)\end{array}$} \\
\hline & $5(3)$ & $1(0)$ & $2(1)$ & $(0)$ & \\
\hline & $6(0)$ & & $2(0)$ & $3(0)$ & \\
\hline \multirow{2}{*}{ oft } & $15(4)$ & $3(0)$ & $6(2)$ & $4(0)$ & \multirow{2}{*}{$28(6)$} \\
\hline & \multicolumn{2}{|c|}{$18(4)$} & \multicolumn{2}{|c|}{$10(2)$} & \\
\hline
\end{tabular}

図 1 原発性肝癌切除症例 術後生存期間 国立長崎中央病院外科（S. 47. 1 S. 60.6）

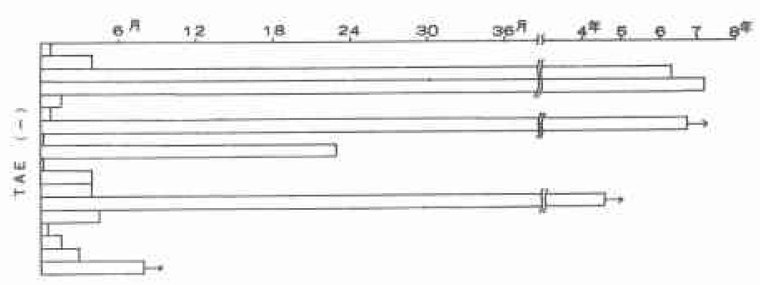

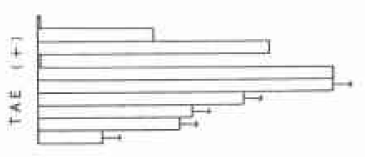


表 4 TAE 併用肝切除症例 国立長崎中央病院外科

\begin{tabular}{|c|c|c|c|c|c|c|c|}
\hline \multirow[b]{2}{*}{ 症例 } & \multirow[b]{2}{*}{ 年令 } & \multirow[b]{2}{*}{ 性 } & \multicolumn{2}{|c|}{ 㗐惪 } & \multicolumn{3}{|c|}{ T A E } \\
\hline & & & 数、位国 & 大きさ & 物 霓 & 回数 & 日 数 \\
\hline 1 & 65 & 女 & S-PA & $10 \times 7 \mathrm{~cm}$ & 湅 部 & 1 & 51日 \\
\hline 2 & 43 & 男 & S-PA & $9 \times 7$ & 耕 片 & 1 & 36 \\
\hline 3 & 34 & 男 & $S-L$ & $1 \times 1$ & 絽 片 & 1 & 34 \\
\hline 4 & 3.3 & 男 & $M-A P$ & $9 \times 7,1 \times 1$ & $M M C-m i c$ & 2 & 45 \\
\hline 5 & 65 & 男 & $S-P$ & $3 \times 3$ & 細 片 & 1 & 36 \\
\hline 6 & 60 & 男 & $S-A$ & $3 \times 3$ & 細 片 & 1 & 42 \\
\hline 7 & 59 & 男 & $M-L M$ & $2 \times 2,1 \times 1$ & Ivaron & 2 & 273 \\
\hline 8 & 53 & 男 & $S-P$ & $1.5 \times 1.5$ & 稩 柆 & 1 & 58 \\
\hline 9 & 43 & 女 & $S-P$ & $2 \times 1$ & 初 片 & 1 & 45 \\
\hline 10 & 53 & 男 & $S-A$ & $2 \times 2.5$ & 紐 片 & 1 & 48 \\
\hline
\end{tabular}

\begin{tabular}{|c|c|c|c|c|c|}
\hline $\begin{array}{l}11 \\
12\end{array}$ & $\begin{array}{ll}67 & \text { 男 } \\
64 & \text { 男 }\end{array}$ & $\begin{array}{l}M-P A L M \\
M-P L\end{array}$ & 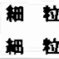 & $\begin{array}{l}2 \\
1\end{array}$ & $\begin{array}{l}80 \\
61\end{array}$ \\
\hline
\end{tabular}

表 5 TAEによる腫瘍抑制効果

\begin{tabular}{|c|c|c|c|c|c|c|c|c|c|}
\hline & \multicolumn{4}{|c|}{ 主 $\quad \mathbf{m}$} & \multicolumn{2}{|c|}{ 回望怪 } & \multirow{2}{*}{ และ十 } & 韭整数 & \multirow{2}{*}{ 拜现变 } \\
\hline & 中心暗 & 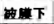 & 典斟内 & \#醋外 & 19 & 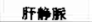 & & 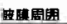 & \\
\hline 1 & $(+)$ & $(-)$ & $(-)$ & $(-)$ & $(-1)$ & & & 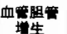 & 乙 \\
\hline 2 & $(+)$ & $(-)$ & $(-)$ & $(-)$ & & & & . & 乙 \\
\hline 3 & (H) & $(+)$ & $(+)$ & & & $(+)(?)$ & & . & 甲 \\
\hline 4 & (\#) & $(+)$ & $(+)$ & $(-)$ & $1+1$ & & $1-1$ & . & $\$ \iota$ \\
\hline 6 & $(\#)$ & (H) & $1+1$ & & & & & . & なと \\
\hline 6 & (\#) & $(\#)$ & $1+1$ & & & & & - & な \\
\hline 7 & $(-)$ & $(-)$ & $(-)$ & $(-1)$ & $(t-)$ & & & . & z \\
\hline 8 & $(-)$ & $(-)$ & $(-)$ & $(-1)$ & & $(+)(?)$ & & . & z \\
\hline 9 & $(+)$ & $(+)$ & $(-)$ & $(-)$ & & & & - & z \\
\hline 10 & (\#) & (\#) & $(-1)$ & & & & & . & te $\mathrm{L}$ \\
\hline 11 & (\#) & $(+)$ & & & & & (\#) & - & アルコール6 \\
\hline 12 & $(\mathrm{H}$ & (t+) & $(\pi)$ & $1+1$ & & & & . & $z$ \\
\hline
\end{tabular}

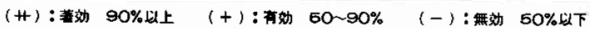

$4)$. 年齢は $33 \sim 65$ 歳, 平均 52.4 歳であり, 男10例, 女 2 例であった。切除例の腫瘍は, 単発性 8 例, 多発性 2 例で，大ささは，直径 $5 \mathrm{~cm}$ 以下が 7 例， $5 \mathrm{~cm}$ 以上が 3 例であった. TAEの塞栓物質は, スポンゼル細粒 4 例, 細片 6 例, MMC-microcapsule 1例, アイバロン 1 例である. TAE 回数は 1 ～ 2 回，TAE より手術ま での期間は34日より最長273日であった。

6. TAE 併用肝切除例の病理組織学的所見

TAE に上る抑制効果を，壊死率 $90 \%$ 以上を著効, 50－90\%を有効，50\%以下を無効として示した。 なお， 壊死率は腫場の最大割面のほか $2 \sim 3$ の割面にて壊死 の範囲を算出した。主腫場の中心部は 12 例中 7 例が $90 \%$ 以上の壊死率を示したが, 症例 $7 ， 8$ は $50 \%$ 以下 であった. 通常, われわれは TAE 後約 1 カ月を経てか ら肝切除を行っているが，症例 7 はアイバロンによる $\mathrm{TAE}$ 後 9 カ月を経過して切除したもので，側副動脈 の発達が考克られ, 症例 8 は TAE 後の術直前の血管 造影にて, 腫瘍の膿染像が認められ TAE が不十分で
あったものである。一方，腫湯の被膜外浸潤は 7 例に 認められたが， 6 例ではTAEの効果は認められな かった. 門脈内腫瘍栓は 3 例中 2 例が無効であり, 肝 静脈内腫瘍栓のみられた 2 例には，わずかの viable cell を残して壊死が認められたが，1例の主腫瘍の壊 死はほとんど認められなかった。娘結節は 2 例に認め たが 1 例に著効を示した（表 5 ）。

\section{IV. 考 察}

原発性肝癌の治療は, 現在でも遠隔転移のない場合 には肝切除が第一に選択されるべき治療法であるが， 本邦に括ける肝癌には肝硬变が併存することが多 ( ${ }^{1)}$, 肝切除後の死亡率子肝硬変 (一) 群の $11 \%$ に対し て肝硬変 $(+)$ 群では $23 \%$ と高率である3)。われわれの 切除例でも, 肝硬变 (一) 群では部分切除ではもとよ ク，二区域切除でも手術死亡例はみられず，肝硬変が 併存しない症例では，いずれの術式を選んでも安全に 肝切除は可能であるが, 肝硬变 $(+)$ 群では部分切除 8 例には手術死亡が認められなかったものの，一一二 区域切除では 13 例中 6 例 $46.2 \%$ に手術死亡がみられ た。これらのことは肝硬変併存肝癌症例では肝の切除 量を少なくすることが手術成績向上の一因であること を示すすのであろう.

そこでわれわれは，肝切除前に TAEを施行するこ とで, 腫場の発育進展を阻止し, さらに, 術中の癌細 胞散布を阻止できれば, 非癌部肝組織の切除量を減じ ても, 癌の切除療法としての根治性が高められるので はないかと考光，昭和56年より TAE 併用肝切除を施 行してきた。 山崎らは4)この TAE 併用肝切除の遠隔成 績を TAE 非施行例と比較し, 現時点では両群に有意 差はなかったと述べている．われわれの肝切除後の生 存期間をみても, TAE (一) 群の多くが 6 力月以内に 再発死亡しているのに対し TAE $(+)$ 群では術後の生 存期間をやや延長させたように思われたが，3 例が再 発にて術後 8 力月, 18 力月, 24 力月にそれぞれ死亡し て㧍り，必ずしも再発の防止はできていないようであ る.

われわれは, TAE の有効性を検討するために, TAE 後肝切除を施行した10例と TAE 後早期に他病死した 2 例の剖検例で肝の組織学的検討を行ったが，主腫瘍 の中心部に対する効果は認められても, 被膜内腫場組 織, 被膜外浸潤部, 門脈内腫湯栓, 娘結節には, 他の 報告にもみられるごとく ${ }^{5 / 6)}$, 効き難く, viable な癌細 胞が残存し，再発の一因となるのであろうと考兄られ た。 
しかしながら，個々の症例をみると，TAEの有効性 を示唆するものがある.

症例12では被膜外浸潤部の壊死がみられたが（写真 1), 本例では塞栓物質として Spongel Powder ており，ょり末梢まで塞栓されたものと考えられた。 症例 4 では, 門脈内腫瘍栓の壊死がみられたが（写真 2), 本例では，われわれが独自に開発した徐放性の MMC-microcapsule ${ }^{7)}$ 塞栓物質として chemo-embolization を行っている. 症例11では, 娘結節も $90 \%$ 以 上の壊死を示したが (写真 3,4), 本例では Spongel PowderによるTAEを 2 回施行している.

すなわち、これらのことは TAEの方法や塞栓物質 を改良すればTAEの有効性が増強されることを示唆 するものである。

肝癌の外科的治療において, 肝切除量の制限はその

写真 1 症例12.病理組織所見 (H.E. 3.3X). 被膜外 浸潤部に壊死を認める。

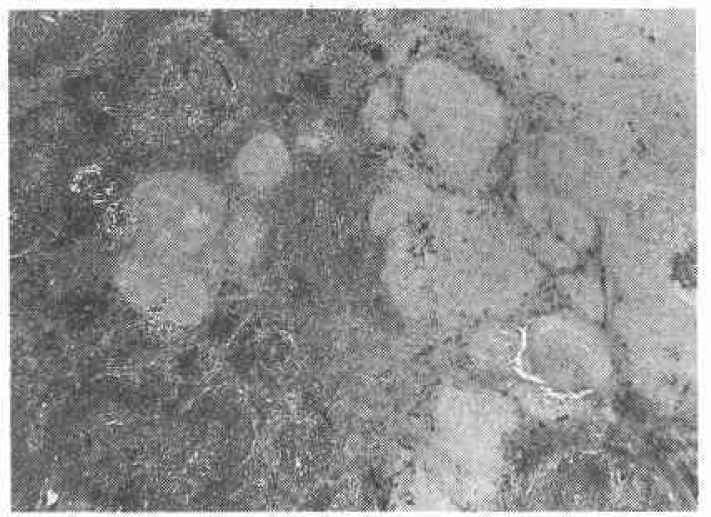

写真 2 症例 4. 病理組織所見 (H.E. 3.3×). 門脈内 腫瘍栓に壊死を認める

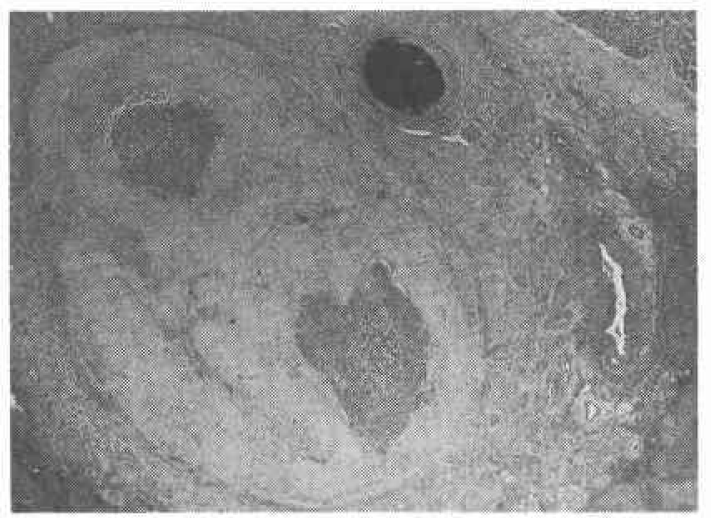

写真 3 症例11. 剖検肝肉眼所見. 主腫啺の完全壊死 と娘結節の壊死を認める。

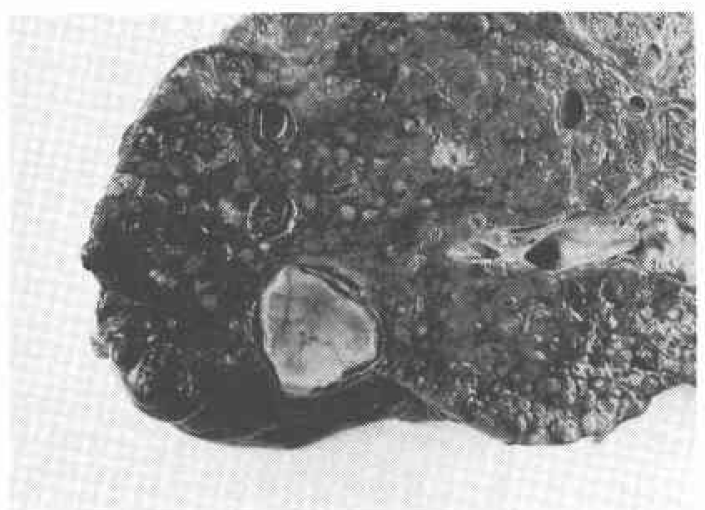

写真 4 症例11. 病理組織所見 (H.E.3.3×). 娘結節 の壊死を認める。

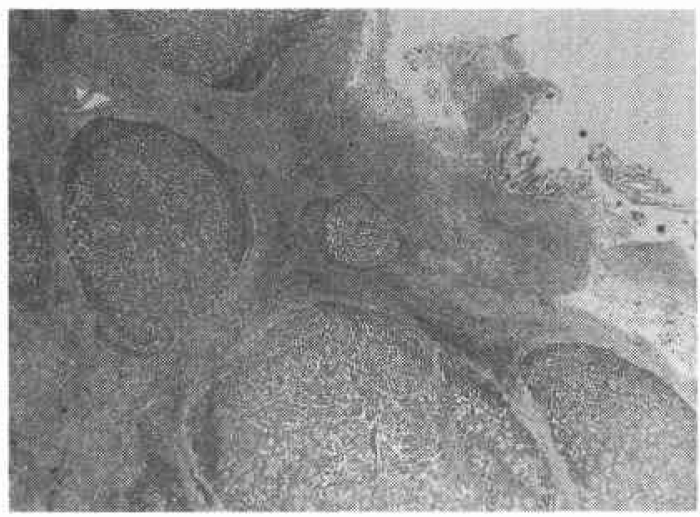

根治性とは逆行しており，術後の肝不全対策を確立し て広範囲な肝切除を行らべきだとの意見すあるが8)， 本邦における肝癌は訮硬変が併存していることが多い ことや，たとえ小肝癌であっても高率に門脈内腫瘍塞 栓がみられ9), 肝細胞癌が常に進行癌の様相を呈して いることを考えると， TAEや肝切除といった単独の 治療法には限界がみられ，TAEの方法や塞栓物質を 改良してその効果を増強させ, さらに, 肝切除の方法 に工夫を加えれば, TAE 併用肝切除によって，たと光 肝硬変併存肝癌であっても, 肝の切除量を少なくし, かつ, 根治的な治療が可能となり, 肝癌の遠隔成績の 向上が期待できるものと考えられた.

\section{V. 結語}

われわれの施設における原発性肝癌の手術成績を述 ベるとともに, TAE 併用肝切除例の組織学的所見の 
検討をした，肝癌切除例に执ける手術死亡例は，すべ て肝硬变併存例の肝区域切除例であり, 肝部分切除や 肝硬変非併存例には認めなかったことより, 肝硬変併 存肝癌では, 肝の切除量を少なくすることが肝切除を 安全に行ら一因であると考㝋られた。 また, TAE 併用 肝切除にて 3 例の再発がみられ，必ずしも治療成績の 向上は認められなかったが, TAEに際し, その回数を 増し, 塞栓物質を細粒にしたり，あるいはまた，MMCmicrocapsule にすることで有效例が認められた。すな わち，集学的治療である TAEを併用した肝切除によ る肝癌の遠隔成績の向上には, TAEの方法, 塞栓物質 の改良が必要と考えられた。

本論文の要旨は, 第69回日本消化器病学会総会ならびに 第44回九州癌学会にて発表した。

なお, 本研究は厚生省がん研究助成金(研究班59-6, 班長 長谷川博) の援助によるものである.

\section{文献}

1）日本肝癌研究会編：原発性肝癌に関する追跡調查 一第 5 報一。肝臟 $23: 675-681 ， 1982$

2) 山田龍作 : 今日の TAE (transcatheter arterial embolization）療法. 臨外 39：939-942, 1984
3）菅原克彦：原発性肝癌切除成績とその向上への歩 み. 日外会誌 $82: 1127-1129,1981$

4) 山崎 晋, 長谷川博, 幕内雅敏：TAE 療法とその 応用一私はこうしている一. 臨外 $39: 955-959$,

- 1984

5）神前五郎, 岡村 純, 岡本篤武ほか：集学的治療に よる肝癌切除の適応. 外科診療 $16: 1129-1134$, 1984

6）厚生省がん研究助成金, 計画研究第15班編：肝癌 に対する集学的治療一Embolization を併用した 肝切除の検討一. 肝胆膵 $5: 1195-1200,1982$

7) 伊藤新一郎, 古川正人, 中田陖則ほか：マイトマイ シンC・マイクロカプセル併用 Transcatheter Hepatic Arterial Embolization $の$ 臨床的応用に 関する研究。長崎医会誌 $59: 25-30,1984$

8）小沢和恵, 谷 友彦, 滰 吉郎ほか：肝癌の集学的 療法一肝動脈塞栓兼肝切除一, 外科診療 25 ： $1127-1138,1983$

9）山崎 晋, 長谷川博, 幕内雅敏 : 細小肝癌の臨床病 理的分析と，それにもとずく新しい概念の切除法 -27 切除例の検討一. 肝缄 $22: 1714-1722,1981$

10）日本肝癌研究会編：原発珄肝癌取扱い規約. 東京, 金原出版, 1983, p4-5 